\title{
Professional Integration of Sociology Graduates from the Lucian Blaga University of Sibiu, 2002-2009
}

\author{
Andreea Simona Popesc ${ }^{2}$ * \\ ${ }^{1}$ Lucian Blaga University of Sibiu, Department of Sociology and Social Work, 2 Lucian Blaga, 550169 Sibiu, Romania \\ 2 Université de Bourgogne, Department of Sociology, 2 Boulevard Gabriel, 21000 Dijon, France
}

KEYWORDS

Higher education

graduates

Professional integration

Social capital

Bachelor's degree

Additional training

\section{A BSTRACT}

The professional integration of higher education students is a problem for all contemporary societies, including the Romanian one. The surplus of graduates, the diplomas' devaluation, the opportunities' inequality and the unequal distribution of labour market's posts are just a few determinant factors, which make the individual to adopt a variety of strategies to get a job.

This research is particularly interested in the integration process on labour markets of sociology graduates in Romanian academic system, taking in consideration the case of sociology graduates from the Lucian Blaga University of Sibiu.

The main objective is to understand all mechanisms of social, economic, cultural and familiar order, susceptible in influencing the individuals when they are searching a job.

The instruments used in this research are based on questionnaire survey and interview. I used these to have an overview of the situation both quantitatively and qualitatively and for a better understanding of the professional integration process. I used the purposeful sample. The results of this research are expected to be able to capture the professional integration process of graduates in sociology from the Lucian Blaga University by identifying some of the factors that influence this process.

\section{Introduction}

The question concerning the rapport between education and economic system which arose as part of sociology concerns since the early 1960s

\footnotetext{
* Contact address: popescsimona@yahoo.com (A. S. Popesc).
} 
(Tanguy 1986) is today put in terms of relationship between education and occupation. There was a period in the history of industrial societies' growth that has been preoccupied with 'promoting intellectual resources' and where the spreading of education was seen as a necessary condition for the development of these societies. This period, however, succeeds crisis in which the spreading of education causes tensions on labour market. These tensions were caused by a general compulsion of jobs by which the diploma becomes a condition more and more necessarily but, also insufficient to access skilled jobs. Thus, the question appeared: what else, besides the bachelor's degree, is required on the labour market for a better professional integration (Duru-Bellat 2006)?

Many writers (see for example: Charlot 1977; Baudelot 1981; Tanguy 1986; Teichler 1989; Breen and Jonsson 2005; Murdoch 2006; Perret 2007; Barry 2003) have studied the relationship between initial education and university graduates jobs, in different societies and social groups. The objective was to understand the various mechanisms of social, economic, cultural and family class susceptible to influence when people are looking for a job. The role of academic preparation, of bachelor's degree, of social capital and of additional trainings (other diplomas or abilities in English, computer science or economics), in getting a job are also variables, worthy of study, to better understand the possible processes through which passes a university graduate to get a good job and, if possible, appropriate studies.

There is a strong relationship between education and occupation, even though the scholar position does not turn automatically in a proper social position. The relationship between education and employment should be evaluated according to the duration of studies.

We can see that if the conditions for entering to the labour market have become less difficult in developed countries, in developing countries there is a deterioration of positions between graduates of 1970s and graduates since 2000. This determines the university graduates to undertake also other educations in addition to the initials, to use social networks and to be constantly competing to more easily integrate into the labour market. (DuruBellat 2006).

Education is a condition of the modern world and this was observed in the growth that it took in recent years. Thus in the last fifty years the number 
of students and pupils, in the world, has increased 4.4 times. If the number of students in the world, in 1950s was 6.5 million, in 1997s reached at 88.2 million and continues to grow (Vlăsceanu 2007: 222-225).

After 1989, the Romanian higher education aligned with the current in Western countries and became a mass phenomenon. If in 1956, 1.6\% of young Romanians were integrated in a form of higher education, in 1992 their share was 5.1\% (Cârțână 2000: 108). In 2001-2002, our number of students reported to 100,000 inhabitants was 2598 (Vlăsceanu 2007: 226). A considerable increase if we refer to the communist period, but not so well if we compare it to other countries like ours, where the number of students per 100,000 inhabitants is considerably higher: Slovenia - 4975, Poland - 4641, Estonia - 4437, Bulgary - 2804, Moldova - 2850 (Vlăsceanu 2007: 227).

The number of graduates of higher education in Romania is constantly growing, latest analysis shows that there is a dramatic increase in student population of Romania, from 360,000 in 1998 to over 928,000 in 2007 (Vlăsceanu et al. 2009: 83). In addition to the benefits of the access to education that has become possible for a large part of young Romanians, thereby increasing the country's education, other problems also occur, such as integration of all these young people in labour market in the corresponding positions to the studies they attended. Another problem of extending higher education is questioning its quality.

One of the most important indicators of quality assurance in higher education is the ratio of teachers to students. In the academic year 1990 1991, a teacher of Romanian higher education was attributed to nearly 14 students (13.8). After 16 years, the number of students per teacher increased, reaching to nearly 26 students per teacher, in 2006 academic year. (Vlăsceanu et al. 2009: 85). "This statistic tell us that the time allocated by a teacher to a student decreased by nearly half. Or, that the quality of educational services provided by a teacher to a student in 2006-2007 decreased to half benchmark of 1990-1991" (Vlăsceanu et al. 2009: 85).

According to a national study conducted in 2009 , about $12 \%$ of higher education graduates are already working at the time of graduation (promoting license final exam), $43.8 \%$ managed to occupy a significant job in the first three months after graduation, and $9.4 \%$ between 3 and 6 months from graduation. $14.5 \%$ have never had a significant job in time, and the 
4.3\% have never had a job (Zamfir 2009). In time, after graduation, the incidence of occupational mobility increases, especially for those who were initially classified as unskilled workers (Zamfir 2009).

This research is part of this area of interest. Concepts that are the focus of this research are: education, professional integration, social capital.

\section{Theoretical Framework}

The role of education in society. The education system

A key role of education in the contemporary society is to train professionals who will activate in the labour market and will reproduce social structures. The education system defined in the classical sense means all institutional or informal mechanisms, which ensure the transmission of heritage culture from one generation to another (Bourdieu 2005). When we examine the manner in which the education systems were formed and developed along centuries, we discover that they were depended on religion, political organizations, degree of science development and industrialization, etc. If we detach the education systems, from the historical context where they existed, they would be meaningless (Boudon 2001).

Because of long-term studies and increasing educational qualifications, a large skilled population arises and future generations will be, in terms of individualism, better equipped to enter active life, and in terms of collectively, better prepared to face future (Duru-Bellat 2009). On the other hand, with each day passing, it becomes more uncertain if persevering on the path of scholar inflation also means going on the road leading to progress and social justice. That means that while the access to higher education has increased, the quality of this education has declined (DuruBellat 2006).

It is perhaps interesting to question why the extension of education and increasing skills have asserted in modern society as common policy, that gives the university and its graduates a more increasing influence on individual destinies. This authority is, in fact, characteristic to all modern societies facing a double mission. Firstly, it is that of integrating younger generations into working life, and secondly, of distributing these young 
people to new professions, which have emerged with an amazing speed (Cacouault 2001).

Meritocracy has progressively imposed an essential idea in modern societies. The social position which an individual occupies in the social division of labour should not depend insofar on inherited factors such as own resources, purchased and developed by the individual himself: merit (personal abilities and competences) becomes in this manner the main factor of success. The institution of education, primarily the university, is responsible for developing, nurturing, and selecting this merit (Ballion 1982).

Therefore it can be affirmed that meritocratic system is a condition of modern societies and this system can best be seen in individuals' strategies to integrate into the labour market and the selection criteria.

\section{Professional integration}

The problem of defining the concept of professional integration is a subject of strong debate among economists and sociologists. In most of the authors' opinion, professional integration is a sensible concept that must be handled accurately.

Émile Durkheim (1950) gives a great importance to professional groups in the process of socialization. For him, the professional integration is a socialization process that takes place in the world of work and during all the period in which an individual is integrated into a job.

Jean Vincens (1970) is the first author who puts in a direct way, the problem of defining professional integration. Following him, the concept of professional integration has two meanings, namely: on one hand, it marks the entry of an individual into the work field, distinguished by the fact that the individual used the time different than before, that he devoted a part of his time to a job (where it has benefits, for example, salary). On the other hand, the professional integration is seen as a 'life project' in an economic sense (Vincens 1970). Dominique Merllié (1997) argues that the professional integration means to achieve professional stability.

Following Claude Trottier (1996), several indicators are used to describe the professional integration of graduates: search duration of first job, employment status (permanent or fixed term contract), socio- 


\section{A. S. Popesc - The Professional Integration of Sociology Graduates...}

professional categories of the job, length of unemployment, ratio education/occupation.

Thus, there are lots of meanings for this concept. To achieve a certain typology in this study, I adopted the assumption according to which the professional integration is defined as a process that takes place over a certain period and includes several possible situations: the search for a job, unemployment, training or inactivity (Trottier 1996; Vincens 1970). This point of view takes into account the individuals' professional trajectories, but also the school trajectories.

\section{The role of social capital and social networks in professional insertion}

Most theories on social networks are rooted in the works of Mark Granovetter (1982) who simultaneously tries to establish the theoretical foundations of informal modes of regulation of these networks. Granovetter distinguishes between two types of links: strong links, and weak links, which are presented in most social networks. Before characterizing these relations, Granovetter (1982) divides these interpersonal connections according to their strength. The strength or the weakness of a relationship is evaluated from duration of the relationship, emotional intensity, intimacy, and finally, the mutual services which are made by individuals. There are strong networks when we're talking, for example, about family relationships. Weak connections are rather reflected in relationships with former colleagues of school or work.

However, with the extension of higher education and diplomas devaluation, it is harder for a young graduate to find a job corresponding to his studies. So the range of possibilities narrows, and graduates are 'forced' to use relations increasingly varied (Granovetter 1982, 24-28).

According to Coleman James, the social capital corresponds to the characteristics of social structures that facilitate individual action in the bosom of this structure. The inherent resources of the structure exist independently of the actors' action or intention, being accessible to all community members (Coleman 1988). The social capital is not manifested in the resources that the individual is able to mobilize with the help of his contacts, but takes three major forms that mainly refer to the concept of 
social control: expectations, obligations and trust in social structures; the potential of information included in social relations; the rules and penalties posed by the institutionalization of social relations.

Social networks are ultimately entities whose borders are never completely separated, they evolve and adapt quickly and does not depend on institutions. Many authors (see for example: Coleman 1980; Fukuyama 2002; Putnam 1995; Bourdieu 1980; Bourdieu and Passeron 1964; Trottier 1996; Lemieux 2000; Fornier 2005; Ehrenberg 1991; Deschenaux 2007) demonstrated the effectiveness of network relationships in access to an employment as a response to the problem of unemployment among graduates.

\section{Methods}

This study is exploratory. The universe of population is composed of the sociology/sociology-ethnology graduates from the Lucian Blaga University of Sibiu. I used a convenience sample. The number of respondents by questionnaire is 50 and 11 of those interviewed. I used three large dimensions: educational dimension, employment and social dimension.

This article addresses in an exploratory manner the professional integration of sociology graduates into the labour market and work within the field of sociology. The time passed from the graduation until this study was made (2010) is an important factor that determines the position of subjects in the workforce. In this case the subjects are integrated into the work for 8 years (2002 graduates) to several months after graduation (graduates from 2008 and 2009).

As subjects who work in the field of sociology, we understand not only subjects who are sociologists/ethnologists, but rather the subjects who work in the social sciences (sociologists, ethnologists and also museum curators, managers, teachers, social scientists, etc.).

I used semi-directive interview and the subjects were very open and communicative. One of the most important themes that I have applied in the interview was the strategies the graduates used to get a job.

Both in interviews and questionnaires, I had subjects in each year of graduation. For the years 2002 to 2005, I had between four and five subjects 
for each year and for the years 2006 to 2009 between 7 and 8 subjects per year. Every year, there were more female than male students and this thing was noticed in subjects used in this investigation. $20 \%$ of the total respondents were male and $80 \%$ women

First I proposed to identify the domain of activity the graduates' in sociology from the Lucian Blaga University of Sibiu have, during 2002-2009. After that I pursued to determine the role of the diploma, the scholar success, the social capital and the additional training in getting a job. To achieve these objectives, I put forth the following hypothesis: first I assumed that many sociology graduates are working in other fields, than the studies followed. The second hypothesis refers to the fact that bachelor's degree is not perceived as a guarantee in getting a job in the same field with graduate studies. Third, the marks are an indicator of finding a job in the same field with your studies. Fourth, completing a university degree through additional training (in computer science, English or economics for example) significantly increases the chances of employability. The last one refers to the fact that social capital plays an important role in the access to the labour market in finding more easily a job.

The variables used in this analysis are: university preparation and training, skills learned in higher education, strategies for finding a job, motivation for the present job, social perception of the importance of marks' in obtaining a job.

\section{Analysis and Results}

The importance of higher education, of bachelor's degree and of additional training on the labour market

The knowledge achieved in the faculty is legitimated by the bachelor's degree. How much legitimacy and power do these still have on the labour market? With diplomas devaluation there other selection methods appeared: experience, recommendation, tests, and trainings. These are the key words which we hear more and more often when we are applying for a job. The diploma 'by itself', as a subject said, isn't enough for professional integration; New graduates are often constrained to appeal to other methods 
for successful integration on the labour market. Two of these alternatives are social capital and complementary training.

The proposed hypotheses were verified and confirmed that bachelor's degree is not perceived as a guarantor in getting a job, in the same area with the followed studies and completing a university degree by additional training (in computer science, English or economics) greatly increases the chances of employability.

From the total of respondents, $66 \%$ believe that higher education is important in finding a job in Romania. Nevertheless, a significant percentage, $32 \%$, considered that higher education is not important in finding a job, this depending rather on other considerations (social networks, personal abilities, personality, etc.) than studies followed.

Modern society is characterized by an extraordinary diversity and complexity of services, the work on tape being almost totally replaced. Considering that new jobs require new skills and competencies, we tend to believe that higher education is important to give individuals these skills.

The most common survey responses to the open question 34 (how do you explain that the main university training is not sufficient for finding a job?) were those related to lack of experience, the novelty of the field, nepotism and lack of practice during college. Here are some of them:

- Job market requires well trained people, with experience and this is often the staff's selection criterion.

- Today not only the meritocracy is applying, but also the framing system on job market through cronyism, wealth or "cell".

- We don't learn in college what is required on the job market. For sociology specialization, for example, we should have learned much more statistics.

- Now everyone can get a bachelor's degree which does not encourage the employers to consider this document sufficient for the employment offered.

- Because the degrees were devalued very much and don't matter as they did when you graduated.

$72 \%$ of the subjects believe that bachelor's degree is not enough to get a job in the same field with the studies made and only $28 \%$ believe that it is sufficient.

Subject 7 considers that the bachelor degree without any others formations is not enough for the professional integration: 
In this moment, no, the bachelor degree is not enough and neither is the master, because it's easy for almost each of us to obtain such a degree. In my opinion it's easier to find a job if you attend some postuniversities studies, a bachelor degree or master in another country or some MBA programs - and why not, diplomas such as license, but made in another country.

So, the bachelor degree should be completed with something else, and one of the most common answers is experience:

Many employers ask for experience and for that I consider students should find a job, even part-time and in others fields, during studies. They ask for professional experience in general and sometimes this counts more than a degree. (Subject 8).

Another issue that I proposed in the interviews was to see the link between what is taught in faculty and the labour market requirements. Which are the courses that helped them the most to integrate and if the university is preparing students well enough for the labour market's requirements. At the question 'does faculty prepare students well enough to have a job', Subject 2 answered:

Faculty does not put your arms the manner in which you, future sociologist, will perform where you will be hired. It gives you the leverage, you can use them afterwards. No university will train you $100 \%$ for what to do in the workforce. That is clear.

So, we saw that the bachelor's degree is not perceived as sufficient for insertion in the labour market; degrees can open doors but they are not a guarantee in getting a job in the field of the attended studies. An example of what else is matter in the access in the labour market is the point of Bourdieu (2007). He emphasizes that the academic and professional success depends very much on the origin and the individual's social capital.

Nationally, the diploma is a quality indicator only for $36 \%$ of employers (Vlăsceanu et al. 2009: 145). Another important aspect of quality of higher education in Romania is related to the connection between theoretical and practical training during university. The number of employers who think that graduates have a good theoretical preparation is almost double the number of employers who think they have also a proper practical training $(51 \%$ vs. $27 \%)$. This can define the perception of universities, by employers, as providers of well-trained graduates in theory, but not as well prepared in practice (Vlăsceanu et al. 2009: 145-146). 
Of the total respondents, $82 \%$ believe that an additional training in English, computer science or economics greatly contributes to a successful integration into the labour market. The same result was found in interviews. Regarding this aspect, subjects consider:

They are necessary, primarily due to the mobility and autonomy. I think it provides you a certain degree of safety and also an independence from any organization. (Subject 1).

These have a really important role because without a foreign language and computer skills nobody wants you; that is how it is working today in any field. (Subject 3).

Yes, any kind of additional training can help you at one moment. Labour market is instable and never knows when you suddenly have to reconvert. (Subject 8 ).

Subject 2 believes that some training helps you not only professionally, but also personally:

I recommend them, yes I do recommend. The man when he reaches a job I can't say that ....he caps, but he is no longer so interested ...especially these times, of this transition that never ends, you are obsessed with other things in life that become a priority, and then, normally for you, personally....only some time left. That's why, I say, they are welcome. Any form of training, continuing education, is welcome. (Subject 2).

At the question 'are there certain conditions in labour market, which employers require'? Subject 8 answers:

(...) most expected work experience, but also a lot of motivation to learn, ability to quickly assimilate information, availability to start from the bottom, ready to stand long hours, willingness to accept small salary at the beginning, availability to continue your training through other courses. (Subject 8).

Subject 1 said that the employer wants from his future employee: 'To be competent, capable, abiding'. At the question 'do the students acquire these skills in university?', the same subject says: 'Yes, they receive certain discipline and seriousness.'

According to respondents, the diplomas have been devalued, the university is no longer working at maximum capacity, and the extension of higher education has less positive effects: increasing number of university graduates, many different specializations and the inexistence of appropriate jobs to these specializations in the labour market, etc. 
The subjects have answered that skills and competencies like: seriousness, knowing at least one foreign language, computer knowledge, discipline, dedication are things that matter for employers and help an individual to find a good job

According to the study made by ARACIS (Vlăsceanu et al. 2009) on the quality of higher education in Romania, the requirements that employers consider as very important in the selection and hiring are: employee's ability to organize at the workplace (97\% - important and very important), ability to work in team (96\%), ability to communicate (96\%), punctuality (93\%), morality $(90 \%)$.

The proposed hypothesis are confirmed: bachelor's degree is not perceived as a guarantor in getting a job in the same area with the followed studies and completing a university degree by additional training (in computer science, English or economics) greatly increases the chances of employability.

The role of social capital and social networks in professional insertion

One of the proposed objectives in this study refers to the role of the social capital in the integration on the job market (identifying the role of social capital in finding a job). The proposed hypothesis is: social capital through social networks plays an important role in the access to employment by finding a job easier. The first step in analyzing this issue is to identify the ways in which the graduates found their first job.

Consequently, social networks represent the second method used by the graduates in obtaining a job; this means that the social networks have a big influence in getting a job. By qualitative analysis I will try to show how this thing happens and why. 
Figure 1. The ways in which graduates are finding their first job

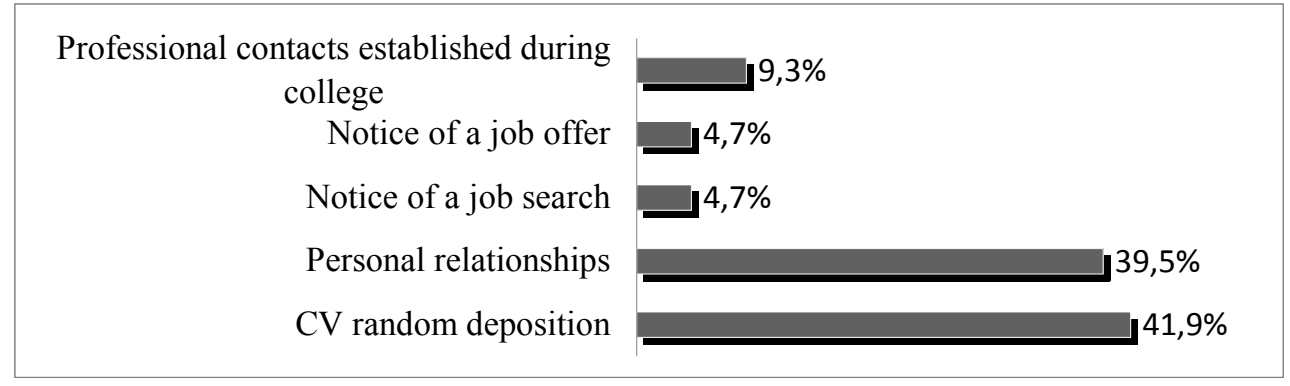

At the question 'what is the role of social networks in obtaining a job?' subjects offered answers like:

Most of the jobs are very quickly occupied and not by honest criteria, based on education, on how good you are in a field, but on who knows who, who you can recommend... (Subject 6).

I would not blame the system so much because at some point you are afraid and you want to have people near you, people that you trust and you can rely on. (Subject 1 ).

(...) how to tell you?!!! One is the nepotisms and other relations. When you are recommended by a teacher is not about relationships. But I have also clear knowledge about a company where, I can say that $70 \%$ of those who hold management positions were employed based on nepotism. (Subject 2).

Subject 5 finds that social networks influence or even determine the distribution in labour market:

Unfortunately, this is the situation, it's about our mentality. And it is a problem, yes. We must, as sociologists, try to change it, and by our example of sociologists who can change things, we can change people's mentality. It's possible, if it's desired, it's possible. There are bad models, too many bad models. I think that this is the only explanation. It's not happening everywhere, you cannot say that everything is black, because not everything is black, but... in some major sights it's seriously such as education... education is a very important area in a society, and there are bad models in all structures, education isn't good everywhere. It's more a mentality... of relations than... meritocracy. (Subject 5).

Subject 8 did not agree with this point of view: 
This happens only in state institutions or lower-level positions that do not require extensive knowledge, like a salesman, or secretary. Rarely a private employer, who is looking for someone specialized, will employ someone that is recommended, but who does not have experience, knowledge, attitudes and all the skills needed for that job. (Subject 8).

The importance of social capital in labour market access has been noted along the years by many authors in their studies (Barry 2003; Bausoleil 1988; Lemieux 2000; Trottier 1995). Beausoleil (1988) made a survey on graduates of higher education in Montreal and came to the conclusion that social networks play an important role in labour market access. This can be explained by the fact that modern societies in labour market always require new skills, competencies, trust and social networks, which sometimes value more than a diploma.

There is also evidence related to the importance of social networks in obtaining a job in a national study, where $42 \%$ of respondents believe that 'in vain you have a degree if you do not have relationships' (Vlăsceanu et al. 2009: 156).

We conclude therefore, that social networks influenced the labour market integration, in a direct or indirect mode. But this capital should not be understood like nepotism, even if in this case the general trend was to blame the favouritism in detriment of meritocracy. The recommendations which come from the part of some competent people represent a part of some-ones' social capital.

By this analysis we confirmed the hypothesis proposed and the result is visible: the social capital through social networks plays an important role in the access to employment by finding a job easier.

\section{The students' field of activity}

Of the total of respondents, $78 \%$ do not work in sociology and only $22 \%$ practice in the field. To better analyze data related to the occupation I recoded the question of the occupation of the subjects, dividing the occupations into three categories: the first category, where we integrated the occupations from the field of studies, this particular category includes: sociologists, researchers, managers, university professors, etc; the intermediate positions or second category comprises people who work in 
commerce, financial, banking or insurance activities, teachers in high schools, etc.; and the third category where we have low-skilled and skilled workers. I haven't brought here the unskilled workers because it was not the case in this study.

Of the total respondents, $70 \%$ are in the second category, the most common occupations being: assistant manager, computer operator, sales agent, financial advisor, teacher, banking operator. $24 \%$ of the subjects covered the first category, the most common occupations are: project manager, researcher, sociologist, curator, higher education framework. $6 \%$ of subjects are in the third category as skilled workers.

After data analysis I can say that the proposed objective was reached and I identified which is the activity domain of the graduated students, and the hypothesis was confirmed. Most of the sociology graduates don't work in the same domain as their studies.

School success - an indicator of the professional success. The marks' importance

The next factor discussed in this casual relationship is the school success as an indicator of the professional success. We chose as an indicator of scholar success the average of the three or four study years. Maybe it's not the best indicator, certainly it's not the only one, but I used it because I considered it's important and quantifiable. I will analyze the marks' importance in the professional life into a quantitative manner and at the same time into a qualitative one, trying to see if the marks' have a big importance in the insertion into professional life.

Do the employers look at marks'? Does the school success transform in professional success? What's the importance of the marks' for an individual? These are some of the questions that I asked in the interview. At the question 'Do you think that marks' during the higher school are an indicator of professional success or rather failure later?', Subject 6 replies:

On the labour market the marks' don't matter'. Now maybe, if you have an employer who looks normal that it makes a different impression about his future employee, I don't say no. But only few people are looking into a transcript to see your marks or degree marks. (Subject 6). 
At the question 'can school success transform it in a professional one?' the same subject says:

Yes and no ... now depends on luck. Maybe you are lucky to find a good job and in school you weren't brilliant or you can find a good job and in school you were also good. Now depends of the cell, knowledge and relationships. I know quite a few cases, from our class who were not brilliant at school, but they got very good jobs because they have their mother, father, and other relatives in the company... and naturally... they have succeeded. (Subject 6).

At the same question Subject 11 respond:

Professionally I'm a failure, and in faculty, really I wasn't a bad student. You learn, you invest in you... in this moment I'm very disappointed, you graduate and you don't find a job...I have a low-paid job but I do this to survive. I really tried, in the last two years; I had five jobs and I have changed two towns... Life is just not fair! (Subject 11).

Subject 10 says that there are situations in which the mark counts:

It depends on what kind of job you have. In the budgetary sector the marks are important, but in the private one, it does not matter how good you were in school. (Subject 10).

Subject 2 has a different point of view:

Any employer is looking at CV, and of course at marks'. He looked. Even if you don't realize that he looked, he did. When he sees a transcript with good grades, he says "oh this is good", or "he was good". The marks are sometimes subjective, it's true, but they represent an indicator. (Subject 2).

At the question 'does scholar hierarchies transform in professional hierarchies?', the same subject answers that this would be the trend:

So that is. I still remain on the same idea. Learn. Especially students that have nothing else to do than to learn, then learn, whatever marks matters. In some fields the employer looked at the marks and he could tell from the start if you were accepted or not. (Subject 2). 
Figure 2. The subjects' occupation by their study years marks

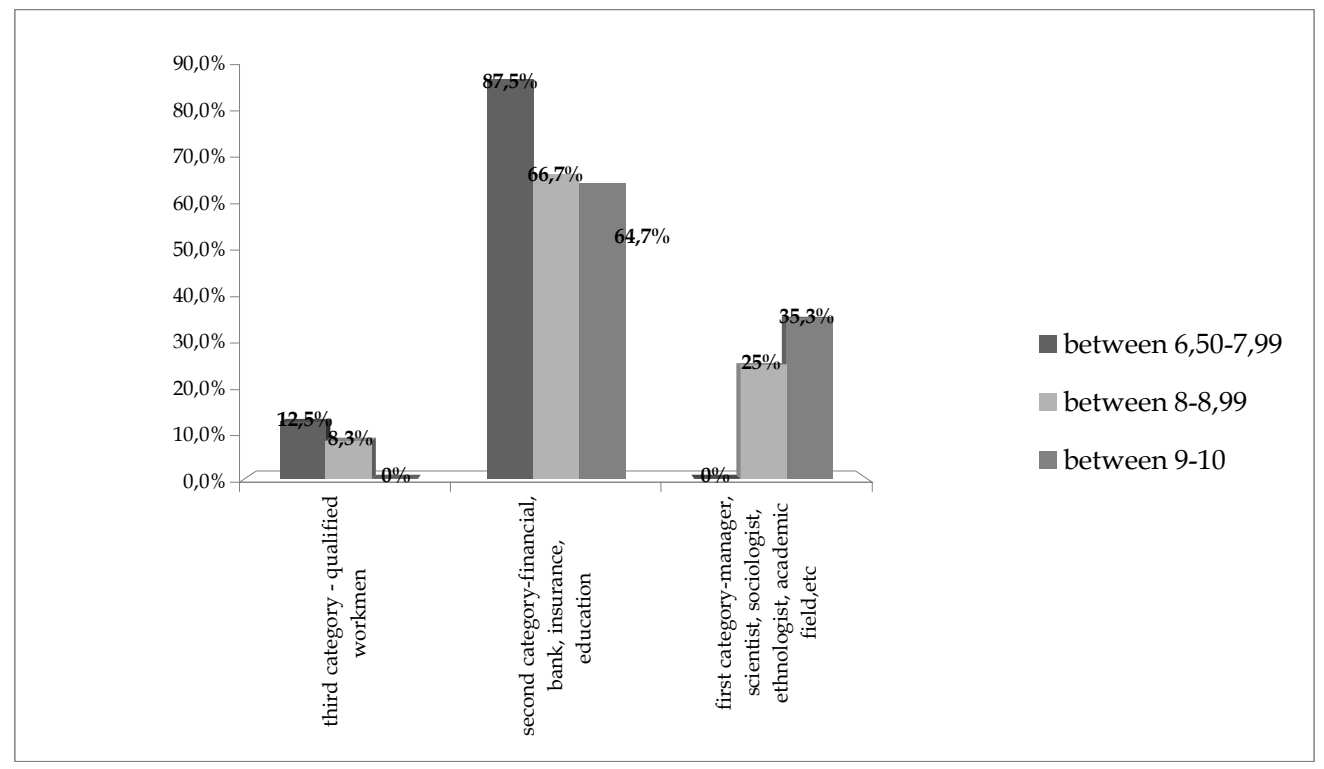

Therefore, the general subjects view is that marks do not always explain professional success and school hierarchies do not always convert into professional hierarchies, but there are cases when this happens. The statistical analysis above shows that generally those with scores between 8 and 10 are in the middle and superior group. The proposed hypothesis is confirmed, marks are an indicator in finding a job in the field study. As I said before, to explain a successful integration into labour market should take into account several factors, not just one, some of them were analyzed in this study.

Therefore we conclude that the professional integration of graduates of higher education is complex and has multiple implications in social field. The situation is more fragile when we refer to the sociology domain because of its novelty in Romania.

\section{Conclusions}

It's obvious that the university leaves a footprint to the individual and helps to define him as a man. This study aimed to understand the professional integration of a small sample of sociology and sociology-ethnology 
graduates from the Romanian university system, educated at Lucian Blaga University, Department of Sociology, 2002 - 2009 and emphasized a few factors that influenced the passage of education and labour market in respect to the graduates of sociology/sociology-ethnology.

There is a tendency to treat professional integration as a simple passage without interruption, from the university system towards the labour market. In facts, things are more complex, the integration is a combination of situations, from basic training to continuing education, from social capital importance, to additional training value. The present analysis discusses the link between training and employment among graduates in sociology/sociology-ethnology and from here, the eternal question on the main academic inadequacy of the bend of work.

An objective of this study was to identify the role of bachelor's degree in obtaining a job. Hypothesis was proposed: bachelor's degree is not perceived as a guarantor in getting a job in the same area with the followed studies. The main purpose was attained, after analyzing the data, confirming or refuting this hypothesis. To achieve that, we used both the quantitative and qualitative analyses.

From the total of respondents, $72 \%$ believe that bachelor's degree is not enough to get a job in the same field studies and only $28 \%$ of them believe that it is enough. The hypothesis was confirmed, we saw that the bachelor's degree is not perceived as sufficient for the insertion in the labour market; degrees can open doors but are not a guarantee in getting a job in the field of the attended studies.

After analyzing data, we managed to touch the second study objective, to identify the importance of additional training (in English, computer science or economics) in getting a job and the hypothesis proposed: by completing a university degree with additional training, the chances for professional integration increase. The hypothesis was confirmed. Nearly $82 \%$ of the students find additional training very important or important. The most mentioned trainings among the respondents were: foreign languages, computer science, management courses and courses at the border with sociology.

From the point of view of the qualitative analysis, subjects think that the supplemental formations: 
(...) have a very important role, because without a foreign language, minimum a foreign language and knowledge in some computer programs they do not pick you, because this is the way it works today in any domain. (Subject 3).

Firstly, they are necessary because of mobility and autonomy. I think it assured a grade of insurance and at the same time independency of any organization. (Subject 1).

Another study objective was the identification of social capital in obtaining a job. The hypothesis suggested for this object was that the social capital by social networks plays a very important role in the access on the work market, to find a job easier. The verification of the hypothesis was achieved by qualitative and quantitative analysis. From the social networks point of view, the majority of the subjects confirmed the importance of the social networks in Romanian context, in finding a job. Approximate half of the subjects consider that these habits are regularly fulfilled in the job market in Romania, 39,53\% of these admit that they obtained their first job after finishing their studies by personal relationships.

The next objective consisted in finding the domain of activity of the graduates of sociology Lucian Blaga University. The hypothesis referring to this aspect suggested that the graduates did not work in the same domain they studied was confirmed. Through the domain studied we did not understand just the sociology working or ethnology, but all the area of social sciences. We analyzed this objective just with the help of quantitative analysis, of the questionnaire. The results obtained were: from the total of the subjects questioned, $78 \%$ did not work in the domain and $22 \%$ work in the domain. To see exactly what it means the subject works in their domain, we split the occupations in three categories, first category, second category, third category. $70 \%$ of them are in the second category, the most used occupations were: manager assistant, computer operator, selling agent, financier consultant, institutor, teacher, bank transaction operator; $24 \%$ of them are in the first category: project manager, researcher, sociologist, curator, teacher in university. $6 \%$ of the subjects, such as qualified workers are found in the third category.

Another objective of the study was to surprise the way in which school success influences professional success. The hypothesis suggested was that the grades during the studies are an indicator to find a job in the studied 
domain. This objective, analyzed with qualitative and quantitative analyses' shows a viable result. I analyzed the present occupation of the subjects depending on the average studies. I chose the grade as an indicator for school success because this can be quantified. From a total of the subjects with years of average studies between 9 and $10,35.3 \%$ are framed in the first category, $64.7 \%$ in the second one. There isn't any subject with average between 9 and 10 framed in the third category. From a total of the subjects with the average between 8 and $8.99,25 \%$ are framed in the first category, $66.7 \%$ in the second one, and $8.3 \%$ in the third category. Among the subjects with the average between 6.50 and $7.99,87.5 \%$ are framed in the second category and $12.5 \%$ in the third one. There aren't any subjects in the first category with an average between 6.50 and 7.99.

Generally, the subjects considered that school hierarchies don't always convert into professional hierarchies. The statistic analyses show us that from the total of subjects, $24 \%$ are framed in the first category, where we find occupations in the sociology field (research worker, sociologist, ethnologist, etc.), or all these had an average between 8 and 10. In conclusion, that this assumption can be confirmed, the grades are an indicator in obtaining a job in the field of studies and they sometimes influence the access to the work market.

Through this study, as I had mentioned, I succeeded to touch the suggested objectives and to check the hypotheses. The problem of integration on the labour market of the graduates is very complex in the Romanian society. The sociology and ethnology graduates of Lucian Blaga University are a small part of the total of youth who confront with the same situations every day and have to undertake diverse strategies to be successful integrated on work's square.

For this study I want to thank first of all to the graduates in sociology from the Lucian Blaga University, who responded promptly to my request and have agreed to share their experience during faculty and employment. I would also like to thank to all the professors of the Department of Sociology and Social Work from Lucian Blaga University for their dedication and commitment that manifested in the act of teaching and also to the professor Horatiu Rusu for his very useful advice and for all the assistance in publishing this article. I want to thank to professor Dorel Morândău, for his professionalism and for the way he guided my steps in the fascinating field of sociology. This study and other successes would not have happened without his invaluable guidance. 


\section{References}

Attali, Jacques. 2009. Le sens des choses. Paris: Robert Laffont.

Attali, Jacques. 1998. Pour un modèle Européen d'enseignement supérieur. Paris: Stock

Ballion, Robert. 1982. Les consommateurs d'école. Dijon: Stock.

Baudelot, Christian, Robert Benoliel and Hubert Curkowicz. 1981. Les étudiants, l'emploi, la crise. Paris : Maspero.

Barry, Mamadou Gando. 2003. Devenir professionnel des diplômés du système Guinéen. M.A. diss., Université de Montréal.

Beausoleil, Jacques, Marie-Chantal Guédon, Claude Larivière and Robert Mayer. 1988. Solidarités, pratiques de recherche-action et de prise en charge par le milieu. Montréal : Boréal.

Bendix, Reinhard and Seymour Martin Lipset. 1966. Class, Status and Power. Social Stratification in Comparative Perspective. New York: The Free Press.

Becker, Gary. 1964. Human Capital. New York: Columbia University Press.

Boudon, Raymond. 2009. Effets pervers et ordre sociale. Paris: Presses Universitaires de France.

Boudon, Raymond. 2001. École et société les paradoxes de la démocratie. Paris: Presses Universitaires de France.

Boudon, Raymond. 1997. Traité de sociologie. Paris: Presses Universitaires de France.

Boudon, Raymond. 1984. L'inegalité des chances. Paris: Hachette Littératures.

Bourdieu, Pierre. 2007. La distinction. Paris: Minuit.

Bourdieu, Pierre. 1999. Rațiuni practice. Bucureşti: Meridiane.

Bourdieu, Pierre. 1984. Homo academicus. Paris: Minuit.

Bourdieu, Pierre. 1980. Le sens pratique. Paris: Minuit.

Bourdieu, Pierre. 1980. Le capital social. Notes provisoires. Actes de la recherche en sciences sociales 31: 2-3.

Bourdieu, Pierre and Jean-Claude Passeron. 2007. La reproduction, éléments d'un système d'enseignement. Paris: Minuit.

Bourdieu, Pierre, Jean-Claude Chamboredon and Jean-Claude Passeron. 2005. Le mètier de sociologue. Berlin: Mouton de Gruyer.

Bourdieu, Pierre and Jean-Claude Passeron. 1964. Les étudiants et leurs études. Paris: Mouton

Bourdieu, Pierre and Jean-Claude Passeron. 1964. Les héritiers, les étudiants et la culture. Paris: Minuit.

Cacouault, Marlaine and Françoise Oeuvrard. 2001. Sociologie de l'éducation. Paris: La Découverte.

Cârțână, Corneliu. 2000. Mobilitatea socială în România. Aspecte cantitative şi calitative la nivel național şi în profil teritorial. Sociologie Românească 1: 105-124. 
Charlot, Alain. 1977. Les universités et le marché du travail: enquete sur les étudiants a la sortie des universités et sur leurs débouchés professionnels. Paris : Centre d'études et de recherches sur les qualifications. Dossier 14.

Coleman, James. 1988. Social Capital in the Creation of Human Capital. American Journal of Sociology 94 (Supplement): S95-S120.

Coleman, James. 1986. Social Theory, Social Research, and a Theory of Action. American Journal of Sociology 91 (6): 1309-1335.

Comşa, Mircea, Cosima Rughiniş and Claudiu Tufiş. 2008. Atitudini față de muncă în România. Bucureşti: Fundația Soros.

Cuin, Charles-Henry. 1993. Les sociologues et la mobilité sociale. Paris: Presses Universitaires de France.

Deschenaux, Frédéric. 2007. Le pouvoir de diplôme. Available online at: http://www.uquebec.ca/-uss1109/dossiers/2007-2008 (accessed December 20, 2009).

Durkheim, Émile. 2009. Les règles de la méthode sociologique. Paris: Flammarion.

Durkheim, Émile. 2007. De la division du travail. Paris: Presses Universitaires de France.

Durkheim, Émile. 1999. Éducation et sociologie. Paris: Quadrige.

Durkheim, Émile. 1950. Leçons de sociologie. Paris: Presses Universitaires de France.

Duru-Bellat, Marie. 2006. L'inflation scolaire, les dessilusions de la méritocratie. Paris: Seuil.

Ehrenberg, Alain. 1991. Le culte de la performance. Paris: Calmann-Lévy.

Frickey, Alan, Jake Murdoch and Jean-Luc Primon. 2006. From Higher Education to Employment: Inequalities Among Ethnic Backgrounds in France. European Education 37 (4): 61-74.

Fukuyama, Francis. 2002. Marea ruptură. Bucureşti: Humanitas.

Giddens, Anthony. 2000. Sociologie. Bucureşti: All.

Granovetter, Mark S. 1973. The Strength of Weak Ties. American Journal of Sociology 78 (6): 1360-1380.

Keeley, Brian. 2009. International Migration: the Human Face of Globalisation. OECD.

Kergoat, Jacques. 1998. Le monde du travail. Paris: La Découverte.

Llored, René. 2007. Sociologie, théories et analyses. Paris: Ellipses.

Lemieux, Vincent. 2000. A quoi servent des réseaux sociaux? Sainte-Foy: Les Presses de l'Université Laval.

Merllié, Dominique. 1997. La mobilité sociale. Paris: La Découverte.

Merllié, Dominique and Prévot Jean. 1994. Les enquetes des mobilités sociale. Paris: Presses Universitaires de France.

Maurin, Louis and Patrick Savidan. 2008. L'état des inégalités en France. Données et analyses. Paris: Belin.

Mills, C. Wright. 1966. Les cols blancs. Paris: François Maspero. 
Paugam, Serge. 2007. Le salarié de la précarité. Paris: Presses Universitaires de France.

Perret, Cathy. 2007. Typologie de l'insertion professionnelle des diplomés d'enseignement superior dans les regions francaise au regard des mobilités géografiques. Revue d'Economie Régionale et Urbaine 2: 293308.

Putnam, Robert. 1995. Bowling Alone: America's Declining Social Capital. Journal of Democracy 6 (1): 65-78.

Renaut, Alain. 2002. Que faire des universités? Paris: Bayard.

Raveleau, Benoît. 2002. L'individu au travail: antagonismes d'une transformation sociale. Paris: L'Harmattan.

Smith, Adam. 2009. La richesse des nations. Paris: Flammarion.

Sorokin, A. Pitirim. 1938. Thèories sociologiques contemporaines. Paris: Payot.

Şerban, Monica and Alexandru Toth. 2007. Piața forței de muncă în România şi imigrația. București: Fundația Soros.

Tanguy, Lucy. 1986. L'introuvable relation formation-emploi. Paris: La Documentation Française.

Teachman, Jay D., Kathleen Paasch and Karen Carver. 1997. Social Capital and the Generation of Human Capital. Social Forces 75 (4): 1341-1357.

Teichler, Ulrich. 1989. Research on Higher Education and Work in Europe. European Journal of Education 24 (3): 223 - 247.

Toffler, Alvin. 1970. Future shock. New York: Bantom Books.

Touraine, Alain. 1978. Lutte étudiante. Paris: Seuil.

Trottier, Claude, Renée Cloutier and Louise Laforce. 1996. La représentation de l'insertion professionnelle chez les diplomés de l'université. Formation-Emploi 58: 61-77.

Trottier Claude, Miala Diambomba and Madeleine Perron. 1995. Les cheminements scolaires et l'insertion professionnelle des étudiants de l'université: perspectives théoriques et méthodologiques. Sainte-Foy: Les Presses de l'Université de Laval.

Van Zanten, Agnès. 2006. Sociologie de l'école. Paris: Armand Colin.

Vincens, Jean. 1970. La prévision de l'emploi. Paris: Presses Universitaires de France.

Vlăsceanu, Lazăr. 2007. Sociologie şi modernitate. Bucureşti: Polirom.

Vlăsceanu, Lazăr, Marian-Gabriel Hâncean, Bogdan Voicu şi Claudiu Tufiş. 2009. Starea calității în învățământul superior. Barometrul calității 2009. Bucureşti: QualMedia.

Zamfir, Ana-Maria. 2009. Mobilitatea ocupațională a absolvenților de învățământ superior în România. Manuscript. 